\title{
Seasonal variation of bacterial load in river and lake waters of Dhaka city, Bangladesh
}

\author{
Md. Suprio Sadat Sikdar ${ }^{1}$, Maruf Abony ${ }^{1}$, Tamanna Zerin²*, Avijit Banik ${ }^{1}$, Suvamoy Datta ${ }^{1}$, \\ ${ }^{1}$ Department of Microbiology, Primeasia University, 9, HBR tower, Banani, Dhaka-1213, Bangladesh. \\ ${ }^{2}$ Department of Microbiology, Stamford University Bangladesh, 51, Siddeswari Road, Dhaka-1217, Bangladesh.
}

\begin{abstract}
Surface water is often contaminated due to human excreta and urban and industrial pollution. The increased population growth and industrialization are likely to exacerbate the situation. Microbiological analysis of waters from rivers (Turag and Buriganga) and lakes (Banani and Dhanmondi) around Dhaka city were conducted for Spring, Monsoon and Fall seasons of the year, 2016 and 2017. Total Viable Count (TVC), Total Coliform Count (TCC), Total Fecal Coliform Count (TFCC) and Total Salmonella Shigella Count (TSSC) were conducted to obtain bacterial load in both enriched and without enrichment water samples. All the Isolates were identified by microscopy, cultural characteristics and biochemical methods. Most of the water reservoirs have a decline in the bacterial load in monsoon where the microbial load of pathogens is highest during spring. Without enrichment, E. coli, Enterobacter sp., Klebsiella sp. and S. aureus were abundant, where others like Shigella sp., Proteus sp., Serratia sp., Pseudomonas sp., Acinetobacter sp., and Alcaligenes faecalis mostly exhibited growth following enrichment. Results indicate that pathogenic environmental isolates can cause serious health issue if water is left untreated or poorly treated from reservoirs within and around Dhaka city.
\end{abstract}

Keywords: Rivers and Lakes, Seasonal variation, Enrichment, Dhaka city

\section{Introduction:}

Water resources as rivers and lakes are natural sources of water for human and animal usage ${ }^{1}$. Polluted water reservoirs containing a large variety of pathogenic microorganisms including viruses, bacteria, and protozoa are mainly originated from the direct and indirect release of feces from humans and warm-blooded animals. The sanitary danger of polluted water usage depends on the purpose of use, type and concentrations of pathogens ${ }^{2}$. According to a joint monitoring programme by WHO/UNICEF in Bangladesh, the percentage of populations using improved drinking water sources are $85 \%$ and $78 \%$ in urban and rural inhabitants, respectively, in the year 2006. The rest are using unimproved drinking water sources including unprotected dug well, spring, small cart with tank/drum, tanker truck and surface water including river, dam, lake, pond, stream, channel, irrigation channel $^{3}$. Water borne diseases are the main reason of morbidity in many developing countries ${ }^{2}$. Therefore, regular monitoring of surface water quality is required in both urban and rural areas to provide information for continuous government interference.

It is practically unfeasible to microbiologically test the quantity and quality for every single pathogen due to their large diversity and scarcity along with time, cost, and complexity of those testing procedures $^{2,4}$. Although molecular techniques as like DNA microarray are available that can detect various microorganisms at the same time, but they are costly and cannot differentiate between living and nonliving pathogens ${ }^{5}$. Hence, monitoring the quality of water is still based on the presence of fecal bacterial indicators ${ }^{6}$. The most widely accepted and frequently used microbial indicators include total coliforms (TC) and faecal coliforms $(\mathrm{FC})^{7}$. Many epidemiologic studies were carried out in the past and still running on liaison between the concentrations of fecal coliform and the risk of illness $8,9,10,11$.

The water borne diseases like diarrhea and gastrointestinal diseases account for nearly a quarter of all illnesses in Bangladesh where water plays a major role in overall disease profile of the country ${ }^{12}$. But, there is very little report on the quality of surface water in Bangladesh. In our study, we included the river, Buriganga passing through southwest skirts of Dhaka city and the river, Turag running by the side of the Dhaka city. Two fresh water man-made lakes, Banani and Dhanmondi lakes, are located in the residential area of Banani and Dhanmondi, respectively, were chosen as well for our study through 3 seasons (spring, summer, and fall) of the year, 2016 and 2017. Major aim of this study was to detect the microbiological quality of waters as well as detection of potential pathogens whose presence may cause waterborne diseases. We also observed the effect of season change, analyzing microbial population by using different methods and effect of enrichment of water samples whose population may be influenced by industrial pollution.

*Corresponding author:

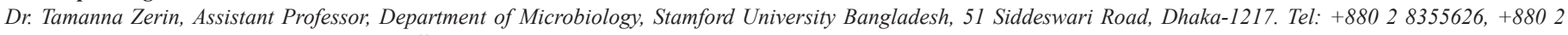
8355596 ext. 478, Fax: +8802 9143531, Cell: +8801715042811

E-mail: tzerin1983@gmail.com 


\section{Materials and methods:}

Study area, sample collection and enrichment

The microbiological assessment of waters was performed from spring, 2016 to fall, 2017. Samples were collected in sterile containers from the rivers, Turag and Buriganga and lakes, Banani and Dhanmondi. During sample collection, temperature were recorded and presented in Table 1 . The study area location is presented in the figure 1 . For enrichment, $20 \mathrm{ml}$ of each water sample was transferred to $80 \mathrm{ml}$ of buffered peptone broth and incubated for $16 \mathrm{~h}$ at $37 \mathrm{U} C$.

\section{Total bacterial count:}

In the present study, Total Viable Count (TVC), Total Coliform Count (TCC), Total Fecal Coliform Count (TFCC) and Total Salmonella Shigella Count (TSSC) were performed for each of the sample by spread plate count technique. Both enriched and without enrichment samples were serially diluted with distilled water following the ten-fold dilution procedure. Afterward, $100 \mu \mathrm{l}$ of diluted water samples were spread onto Plate count agar media (Oxoid, UK) for TVC, MacConkey agar media (Oxoid, UK) for TCC, mFC agar media (Oxoid, UK) for TFCC and SS agar media (Oxoid, UK) for TSSC. The plates were incubated at 37ÚC except for thermotolerant fecal coliforms that grows at $44.5 \mathrm{U} C$ up to 48 h. Following growth, the number of organisms was calculated by multiplying the number of colonies with dilution factor.

\section{Identification of specific bacteria:}

Colonies with significant characteristics from agar plates and Lactose broths were streaked on selective agar media as MacConkey, mFc, SS, TCBS, Cetrimide, MSA and EMB agar media (Oxoid, UK). The plates were incubated overnight at $37^{\circ} \mathrm{C}$ and $\mathrm{mFc}$ were incubated at $44.5^{\circ} \mathrm{C}$ for $48 \mathrm{~h}$. After incubation, the plate cultures were examined for the presence of morphologically distinct colonies. Each isolated colony from the incubated plates was aseptically transferred and streaked in nutrient agar slants (1.5 ml vials) and incubated for $24 \mathrm{~h}$ at 30ÚC. Following incubation, the cultures were subjected to staining and biochemical tests. Biochemical tests that were performed include Kligler's Iron Agar (KIA), Methyl Red (MR), Voges-Proskauer
(VP), Citrate, Catalase, Oxidase, Indole, Urease, Motility, and $\mathrm{H}_{2} \mathrm{~S}$ production. Presumptive identification of the isolates was achieved by examining physiology by microscopy, colony morphology on selective media and biochemical characteristics.

\section{Result:}

The temperature variation was found all through the study time. The highest temperature of all the water bodies was observed during monsoon irrespective of the year (Table 1). We investigated the differences in TVC, TCC, TFC and TSSC when water samples were enriched in peptone enrichment broth for 16 $h$ at $37 \mathrm{U} C$ with without enrichment water samples (Table 2). As assumed, all the bacterial counts significantly increased while the samples were enriched indicated its importance. All the bacterial counts were higher during spring but the count seemed to be greatly reduced during monsoon and then, again somewhat elevated during fall. The pattern of spatial distribution in the bacterial count was comparable within each of the water bodies. Irrespective of the season and year, the counts were mostly higher in the river Buriganga than the river Turag. But, the counts in both the lakes were fluctuated with seasons and years.

Current study revealed predominant presence of E. coli, Enterobacter sp., Klebsiella sp., Salmonella sp., Shigella sp., S. aureus, Pseudomonas sp., and Acinetobacter sp. in the river and lake waters, but Bacillus sp. and Alcaligens faecalis were typically found in lake waters (Table 3). Without enrichment, E. coli, Enterobacter sp., Klebsiella sp. and S. aureus were abundant, where other isolates including Shigella sp., Proteus sp., Serratia sp., Pseudomonas sp., Acinetobacter sp., and Alcaligenes faecalis mostly exhibited growth following enrichment. However, Citrobacter sp. only found in the enrichment culture of the Buriganga river during fall 2016. Besides, Alcaligenes faecalis was also detected from Banani lake during fall for both of the years. Interestingly, Micrococcus sp. was found in without enrichment Banani lake during the seasons spring and fall in the year 2016, they were not found after enrichment. Similarly, Enterococcus sp. was also present in the without enrichment sample of the river Turag during fall 2016. These might be due to the pathogens that outnumbered those organisms.

Table 1: The temperature parameter of different water samples during collection in different seasons of the year 2016 and 2017

\begin{tabular}{llcclc}
\hline Season (Year) & Sample & Temp & Season (Year) & Sample & Temp \\
\hline Spring 2016 & Turag & 20 & Spring & Turag & 20 \\
& Buriganga & 23 & 2017 & Buriganga & 19 \\
& Banani & 20 & & Banani & 20 \\
Monsoon 2016 & Dhanmondi & 21 & & Dhanmondi & 18 \\
& Turag & 27 & Monso on & Turag & 26 \\
Fall 2016 & Buriganga & 27 & 2017 & Buriganga & 24 \\
& Banani & 29 & & Banani & 25 \\
& Dhanmondi & 31 & & Dhanmondi & 23 \\
& Turag & 17 & Fall & Turag & 20 \\
& Buriganga & 19 & 2017 & Buriganga & 19 \\
\end{tabular}




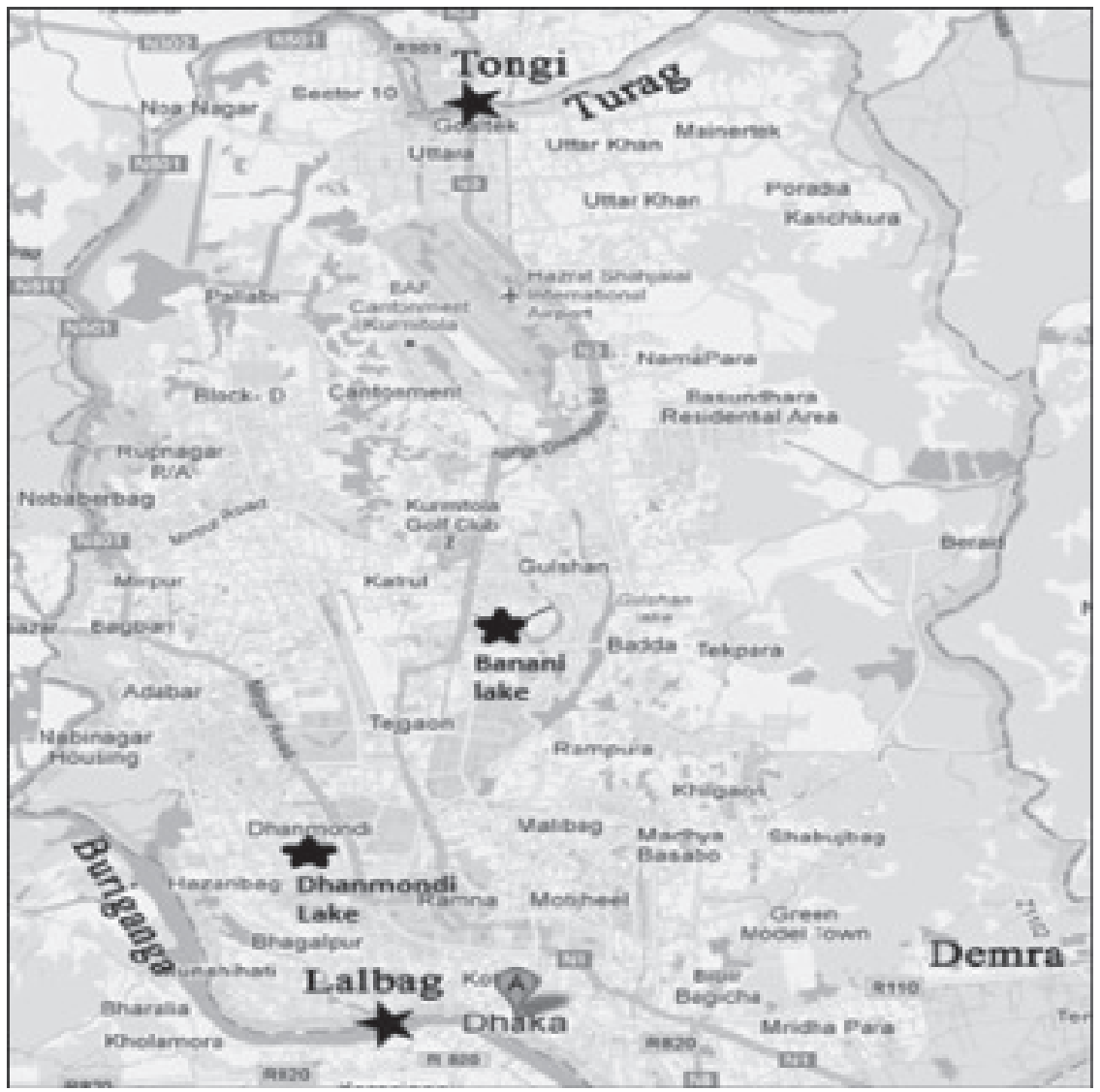

Figure 1. Map showing the four study locations in Dhaka, Bangladesh.

Table 2. The difference in count of TVC, TCC, TFC, TSSC of enriched and without enrichment river and lake water in different seasons of the year 2016 and 2017

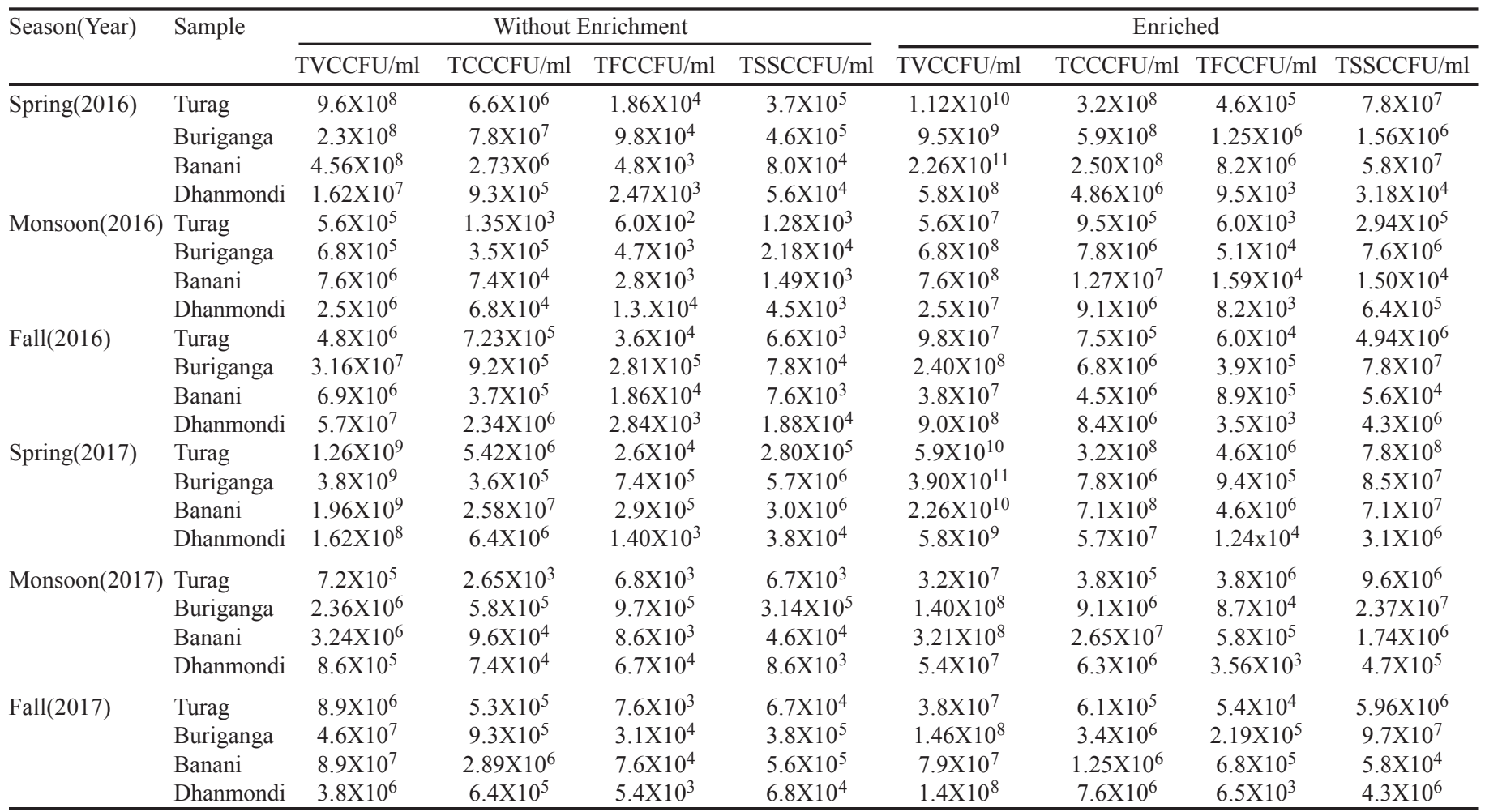


Table 3: Isolated organisms from enriched and without enrichment river and lake water in different seasons of the year, 2016 and 2017

\begin{tabular}{|c|c|c|c|}
\hline Season (Year) & Sample & Without enrichment & Enriched \\
\hline \multirow[t]{4}{*}{ Spring (2016) } & Turag & $\begin{array}{l}\text { S. aureus, Micrococcus sp., E. coli, Salmonella } \\
\text { sp., Enterobacter sp., Pseudomonas sp., } \\
\text { Acinetobacter sp. }\end{array}$ & $\begin{array}{l}\text { S. aureus, Micrococcus sp., E. coli, Salmonella } \\
\text { sp., Shigella } \text { sp., Enterobacter sp., Pseudomonas } \\
\text { sp., Acinetobacter sp., Proteus sp. }\end{array}$ \\
\hline & Burigonga & $\begin{array}{l}\text { S. aureus, E. coli, Salmonella sp., Enterobacter } \\
\text { sp., Pseudomonas sp. }\end{array}$ & $\begin{array}{l}\text { S. aureus, E. coli, Salmonella sp., Shigella sp., } \\
\text { Enterobacter sp., Pseudomonas sp., Acinetobacter sp., Proteus sp. }\end{array}$ \\
\hline & Banani & $\begin{array}{l}\text { S. aureus, Micrococcus sp., Bacillus sp., E. coli, } \\
\text { Salmonella } \text { sp., Enterobacter sp., Pseudomonas } \\
\text { sp., Acinetobacter sp., Klebsiella } \text { sp. }\end{array}$ & $\begin{array}{l}\text { S. aureus, E. coli, Bacillus sp., Salmonella sp., } \\
\text { Shigella sp., Enterobacter sp., Pseudomonas sp., } \\
\text { Acinetobacter } \text { sp., Serretia } \text { sp., Klebsiella } \text { sp. }\end{array}$ \\
\hline & Dhanmondi & $\begin{array}{l}\text { S. aureus, Bacillus sp., E. coli, Salmonella sp., } \\
\text { Enterobacter sp., Pseudomonas sp., } \\
\text { Acinetobacter sp., Klebsiella } \mathrm{sp} .\end{array}$ & $\begin{array}{l}\text { S. aureus, E. coli, Bacillus sp., Salmonella sp., } \\
\text { Shigella sp., Enterobacter sp., Pseudomonas sp., } \\
\text { Acinetobacter sp., Proteus sp., Klebsiella sp. }\end{array}$ \\
\hline \multirow[t]{4}{*}{ Monsoon (2016) } & Turag & $\begin{array}{l}\text { S. aureus, E. coli, Salmonella sp., Enterobacter } \\
\text { sp., Acinetobacter sp. }\end{array}$ & $\begin{array}{l}\text { S. aureus, E. coli, Salmonella sp., Shigella sp., } \\
\text { Enterobacter sp., Acinetobacter sp. }\end{array}$ \\
\hline & Burigonga & $\begin{array}{l}\text { S. aureus, E. coli, Salmonella sp., Enterobacter } \\
\text { sp., Pseudomonas sp., Klebsiella } \mathrm{sp} .\end{array}$ & $\begin{array}{l}\text { S. aureus, E. coli, Enterobacter sp., Salmonella } \\
\text { sp., Shigella sp., Pseudomonas sp., Proteus sp., Klebsiella sp. }\end{array}$ \\
\hline & Banani & $\begin{array}{l}\text { S. aureus, E. coli, Salmonella sp., Enterobacter } \\
\text { sp., Klebsiella } \mathrm{sp.}\end{array}$ & $\begin{array}{l}\text { E. coli, S. aureus, Salmonella sp., Enterobacter } \\
\text { sp., Pseudomonas sp., Klebsiella } \mathrm{sp} .\end{array}$ \\
\hline & Dhanmondi & $\begin{array}{l}\text { S. aureus, E. coli, Salmonella sp., Enterobacter } \\
\text { sp., Klebsiella sp. }\end{array}$ & $\begin{array}{l}\text { S. aureus, E. coli, Salmonella sp., Enterobacter } \\
\text { sp., Pseudomonas sp., Proteus sp., Klebsiella sp. }\end{array}$ \\
\hline \multirow[t]{4}{*}{ Fall (2016) } & Turag & $\begin{array}{l}\text { S. aureus, Micrococcus sp., Enterococcus sp., E } \\
\text {. coli, Salmonella } \text { sp., Enterobacter sp., } \\
\text { Pseudomonas sp., }\end{array}$ & $\begin{array}{l}\text { S. aureus, Micrococcus sp., E. coli, Salmonella } \\
\text { sp., Shigella } \text { sp., Enterobacter sp., Pseudomonas } \\
\text { sp., Acinetobacter sp., Proteus sp. }\end{array}$ \\
\hline & Burigonga & $\begin{array}{l}\text { S. aureus, E. coli, Salmonella sp., Enterobacter } \\
\text { sp., Pseudomonas sp., Klebsiella sp. }\end{array}$ & $\begin{array}{l}\text { S. aureus, E. coli, Salmonella sp., Shigella sp., } \\
\text { Enterobacter sp., Pseudomonas sp., } \\
\text { Acinetobacter sp., Proteus sp., Klebsiella sp., Citrobacter sp. }\end{array}$ \\
\hline & Banani & $\begin{array}{l}\text { S. aureus, Micrococcus sp., Bacillus sp., E. coli, } \\
\text { Salmonella } \text { sp., Shigella } \text { sp., Serretia } \text { sp., } \\
\text { Enterobacter sp., Pseudomonas sp., } \\
\text { Acinetobacter sp., Klebsiella } \text { sp. }\end{array}$ & $\begin{array}{l}\text { S. aureus, E. coli, Bacillus sp., Salmonella sp., } \\
\text { Shigella } \text { sp., Enterobacter sp., Pseudomonas sp., } \\
\text { Acinetobacter sp., Serretia sp., Klebsiella } \text { sp., } \\
\text { Alcaligenes faecalis }\end{array}$ \\
\hline & Dhanmondi & $\begin{array}{l}\text { S. aureus, Bacillus sp., E. coli, Salmonella sp., } \\
\text { Enterobacter sp., Pseudomonas sp., } \\
\text { Acinetobacter sp., Klebsiella } \mathrm{sp} .\end{array}$ & $\begin{array}{l}\text { S. aureus, E. coli, Bacillus sp., Salmonella sp., } \\
\text { Shigella sp., Enterobacter sp., Pseudomonas sp., } \\
\text { Acinetobacter sp., Klebsiella } \text { sp. }\end{array}$ \\
\hline \multirow[t]{4}{*}{ Spring (2017) } & Turag & $\begin{array}{l}\text { S. aureus, Micrococcus sp., E. coli, Salmonella } \\
\text { sp., Enterobacter sp., Acinetobacter sp. }\end{array}$ & $\begin{array}{l}\text { S. aureus, Micrococcus sp., E. coli, Salmonella } \\
\text { sp., Shigella sp., Enterobacter sp., Pseudomonas sp., Acinetobacter sp. }\end{array}$ \\
\hline & Buriganga & $\begin{array}{l}\text { S. aureus, E. coli, Salmonella sp., Enterobacter } \\
\text { sp., Pseudomonas sp. }\end{array}$ & $\begin{array}{l}\text { S. aureus, E. coli, Salmonella sp., Shigella sp., } \\
\text { Enterobacter sp., Pseudomonas sp., Acinetobacter sp., Proteus sp. }\end{array}$ \\
\hline & Banani & $\begin{array}{l}\text { S. aureus, Bacillus sp., E. coli, Salmonella sp., } \\
\text { Enterobacter sp., Pseudomonas sp., } \\
\text { Klebsiella sp. }\end{array}$ & $\begin{array}{l}\text { S. aureus, E. coli, Bacillus sp., Salmonella sp., } \\
\text { Enterobacter sp., Pseudomonas sp., } \\
\text { Acinetobacter sp., Serretia sp., Klebsiella sp. }\end{array}$ \\
\hline & Dhanmondi & $\begin{array}{l}\text { S. aureus,, Bacillus sp., E. coli, Salmonella } \mathrm{sp} . \\
\text { Enterobacter sp., Pseudomonas sp., } \\
\text { Acinetobacter sp., Klebsiella } \mathrm{sp} .\end{array}$ & $\begin{array}{l}\text { S. aureus, E. coli, Bacillus sp., Salmonella sp., } \\
\text { Shigella } \text { sp., Enterobacter sp., Pseudomonas sp., } \\
\text { Acinetobacter sp., Proteus sp., Klebsiella } \text { sp. }\end{array}$ \\
\hline \multirow[t]{4}{*}{ Monsoon (2017) } & Turag & $\begin{array}{l}\text { S. aureus, E. coli, Salmonella sp., Shigella sp., } \\
\text { Enterobacter sp., Acinetobacter sp. }\end{array}$ & $\begin{array}{l}\text { S. aureus, E. coli, Salmonella } \text { sp., Shigella sp., } \\
\text { Enterobacter sp., Acinetobacter sp. }\end{array}$ \\
\hline & Buriganga & $\begin{array}{l}\text { S. aureus, E. coli, Salmonella } \text { sp., } \\
\text { Enterobacter sp., Klebsiella } \text { sp. }\end{array}$ & $\begin{array}{l}\text { S. aureus, E. coli, Enterobacter sp., Salmonella } \\
\text { sp., Shigella sp., Pseudomonas sp., Proteus sp., Klebsiella sp. }\end{array}$ \\
\hline & Banani & $\begin{array}{l}\text { S. aureus, E. coli, Salmonella sp., Enterobacter } \\
\text { sp., Klebsiella } \mathrm{sp} .\end{array}$ & $\begin{array}{l}\text { S. aureus, E coli, Salmonella } \text { sp., Enterobacter } \\
\text { sp., Pseudomonas sp., Klebsiella } \mathrm{sp} .\end{array}$ \\
\hline & Dhanmondi & $\begin{array}{l}\text { S. aureus, E. coli, Salmonella sp., Enterobacter } \\
\text { sp., Klebsiella } \mathrm{sp.}\end{array}$ & $\begin{array}{l}\text { S. aureus, E. coli, Salmonella sp., Enterobacter } \\
\text { sp., Pseudomonas sp., Klebsiella } \text { sp. }\end{array}$ \\
\hline \multirow[t]{4}{*}{ Fall(2017) } & Turag & $\begin{array}{l}\text { S. aureus, Micrococcus sp., Enterococcus sp., } \\
\text { E. coli, Salmonella sp., Enterobacter sp., } \\
\text { Pseudomonas sp. }\end{array}$ & $\begin{array}{l}\text { S. aureus, Micrococcus sp.,Enterococcus sp., } \\
\text { E.coli, Salmonella sp., Shigella } \text { sp., Enterobacter } \\
\text { sp., Pseudomonas sp., Acinetobacter sp., Proteus sp. }\end{array}$ \\
\hline & Buriganga & $\begin{array}{l}\text { S. aureus, E. coli, Salmonella } \mathrm{sp} . \text { Enterobacter sp. } \\
\text { Pseudomonas sp., Klebsiella } \mathrm{sp} .\end{array}$ & $\begin{array}{l}\text { S. aureus, E. coli, Salmonella sp., Shigella sp., } \\
\text { Enterobacter sp., Pseudomonas sp., } \\
\text { Acinetobacter } \text { sp., Proteus sp., Klebsiella } \mathrm{sp} .\end{array}$ \\
\hline & Banani & $\begin{array}{l}\text { S. aureus, E. coli., Salmonella } \text { sp., Enterobacter } \\
\text { sp., Acinetobacter sp., Klebsiella } \text { sp. }\end{array}$ & $\begin{array}{l}\text { S. aureus, E. coli, Salmonella sp., Enterobacter } \\
\text { sp., Acinetobacter sp., Serretia sp., Klebsiella } \\
\text { sp., Alcaligenes faecalis }\end{array}$ \\
\hline & Dhanmondi & $\begin{array}{l}\text { S. aureus, Bacillus sp., E. coli, Salmonella sp., } \\
\text { Enterobacter sp., Acinetobacter sp., } \\
\text { Klebsiella sp. }\end{array}$ & $\begin{array}{l}\text { S. aureus, E. coli, Bacillus sp., Salmonella sp., } \\
\text { Enterobacter sp., Pseudomonas sp., } \\
\text { Acinetobacter sp., Klebsiella } \mathrm{sp} .\end{array}$ \\
\hline
\end{tabular}




\section{Discussion:}

In our study, we observed the diversity in count of TVC, TCC, TFC and TSSC of enriched and without enrichment river and lake waters in three different seasons of the year 2016 and 2017. From our study, it is clearly evident that the count significantly increased during spring which is greatly reduced in monsoon and again, tends to increase in fall throughout the study time. The season monsoon, generally starts from mid May and ends in late October, comprises of extensive rainfall and the latter is a complex variable that usually has different impact on surface water mircobiota. We observed great decrease of microbes during monsoon in any water body irrespective of the year might be because of excessive rainfall that reduced microbial concentration in the water bodies. Whether in another study, it was found that heterotrophic bacterial load in the river Buriganga, Dhaka, Bangladesh increased in the rainy season (July-August) might be due to the runoff ${ }^{13}$.

The season, spring prevails from mid February to mid April and April is the warmest month in most part of the country. Since high temperature accompanied by heavy rainfall which run off human and animal wastes, other organic matters in the water bodies might be the reason for elevated count of indicators and various pathogens. Another season, autumn (fall) starts from mid August to mid October, but late autumn starts from mid October to mid December. Our samples were collected during late autumn when the temperature and rainfall comparatively reduced, the water level in the water bodies got concentrated and bacterial load comparatively improved. The temperature of the water bodies during sample collection is not a true variable as it is recorded just at the time of sample collection, not the average temperature of the three seasons of the year 2016 and 2017.

Our data revealed substantial number of indicators and pathogens present in any of the samples representing precarious for human consumption. The investigated lake and river waters exceeded the maximum safety limit for drinking according to the drinking water quality standard which allows maximum $0 \mathrm{CFU} / 100 \mathrm{ml}$ for faecal coliform (FC), $5 \mathrm{CFU} / 100 \mathrm{ml}$ for total coliform (TC), $100 \mathrm{CFU} / \mathrm{ml}$ for heterotrophic bacterial count, and $5 \mathrm{CFU} / 100$ $\mathrm{ml}$ for enterococci ${ }^{14,15}$. The tested water bodies were greatly exceeded the quality standard for drinking and thus, unsuitable for drinking. The water samples of lakes and rivers tested reside in and beside Dhaka city. Although the urban population rarely uses that kind of water in drinking purpose, which are mostly used in recreational purpose as bathing, washing clothes and utensils etc. The guideline for assessing water quality on different purposes is based on fecal coliform count. The European Economic Community Council has adopted a directive in 1975 for bathing water that indicates TC count should be $500 \mathrm{CFU} /$ $100 \mathrm{ml}$ (the maximum permissible count 10,000 CFU/100 ml), FC count should be $100 \mathrm{CFU} / 100 \mathrm{ml}$ (the maximum permissible value 2,000 CFU/100 ml), no Salmonella is admissible and faecal streptococci (FS) count should be $100 \mathrm{CFU} / 100 \mathrm{ml}$ (Directive 76/160). According to World Health Organization, the water quality standard for primary human contact for FC is $<100 \mathrm{CFU} /$ $100 \mathrm{ml}$ and for $\mathrm{FS}$ is $<100 \mathrm{CFU} / 100 \mathrm{ml}^{16}$. All the water quality standards for drinking and recreational purposes make the tested water bodies very poor in quality. Considering all the parameters, the river Buriganga showed highest bacterial contamination in most of the cases. In a study in 2009, a significant level of organic, chemical and bacterial pollution of the river Buriganga was found ${ }^{13}$. Furthermore, the river, Turag showed that most of the physicochemical parameters were above the safety limit ${ }^{17}$. Physicochemical parameter and questionnaire survey in a study conducted in 2012 reveals severe environmental pollution in Dhanmondi lake by surrounding population and visitors ${ }^{18}$. In our study, a rise in microbial population was observed in the year 2017 in comparison to 2016. A great influence of enrichment in peptone broth for $16 \mathrm{~h}$ was observed in the count of microbial population. All the samples showed increased TVC, TCC, TFC and TSSC when enriched. In some cases, enrichment recovered some pathogenic bacteria which was absent in without enrichment samples. Eventually, lack of knowledge on environmental pollution and unresponsive attitude regarding protection of environment has led the rivers and lakes into a great threat to us. A strict waste disposal system should be practiced to save the quality of the water bodies from pollution and, thus, to reduce the cases of illness.

\section{Acknowledgment:}

The authors acknowledge the kind help of Saiful Islam, Rukhsana Ali, Mahmuda Aktar Akhi and Md. Asikuzzaman, Department of Microbiology, Primeasia University.

\section{Conflict of Interest}

Authors have no potential conflict of interests.

\section{References:}

1. Pathak SP, Bhattacherjee JW and Ray PK. 1993. Seasonal variation in survival and antibiotic resistance among various bacterial populations in a tropical river. J Gen Appl Microbiol., 39: 47-56.

2. Servais P, Billen G, Goncalves A, and Garcia-Armisen T. 2007. Modelling microbiological water quality in the Seine river drainage network: past, present and future situations. Hydrol Earth Syst Sci., 11: 1581-1592.

3. UNSD and ESCAP MDG meeting, Bangkok, 14-16 January, 2009. Data sheet of sanitation and drinking water coverage in Bangladesh.

4. Obi CL, Potgieter N, Bessong PO, and Matsaung G. 2002. Assessment of the microbial quality of river water sources in rural Venda communities in South Africa. Water SA., 28: 287-292.

5. Lemarchand K, Masson L, and Brousseau R. 2004. Molecular biology and DNA microarray technology for microbial quality monitoring of water. Crit Rev Microbiol., 30:145-172.

6. Djuikom E, Njine T, Nola M, Sikati V and Jugnia LB. 2006. Microbiological water quality of the MFOUNDI river watershed at Yaounde, Cameroon, as inferred from indicator bacteria of fecal contamination. Environ Monit Assess., 122: 171-183.

7. Kay D, Bartram J, Pruss A, Ashbolt N, Wyer MD, Fleisher JM, Fewtrell L, Rogers A and Rees G. 2004. Derivation of numerical values for the 
World Health Organization guidelines for recreational waters. Water Res., 38: $1236-1304$.

8. Pru"ss A. 1998. Review of epidemiological studies on health effects from exposure to recreational water. Int J Epidemiol., 27: 1-9.

9. McBride GB, Salmon CE, Bandaranayake DR, Turner SJ, Lewis GD and Till DG. 1998. Health effects of marine bathing in New Zealand. Int $J$ Environ Heal Res., 3: 173-189.

10. Van Asperen IA, Medema GJ, Borgdorff MW, Sprenger MJW and Havelaar AH. 1998, Risk of gastroenteritis among triathletes in relation to faecal pollution of fresh waters. Int $J$ Epidemiol., 27: 309-315.

11. Zamxaka M, Pironcheva G and Muyima N. 2004. Microbiological and physico-chemical assessment of the quality of domestic water sources in selected rural communities of the Eastern Cape Province, South Africa. Water SA., 30: 333-340.

12. Ahmed ZU. BANGLAPEDIA, National Encyclopedia of Bangladesh, modified on 9th February, 2015.
13. Saha ML, Khan MR, Ali M and Hoque S. 2009. Bacterial load and chemical pollution level of the river Buriganga, Dhaka, Bangladesh. Bangladesh J Bot., 38: 87-91.

14. South African water quality guidelines. 1996. Domestic Water Use Second Edition, volume 1.

15. Water research commission (WRC). 1998. Quality of domestic water supplies, assement guide, Volume $1,2^{\text {nd }}$ edition. WRC report no TT101/ 98, Pretoria, South Africa.

16. WHO. 1998. Guidelines for safe recreational-water environments WHO/ EOS/98, Geneva.

17. Mobin MN, Islam MS, Mia MY and Bakali B. 2014. Analysis of Physicochemical Properties of the Turag River Water, Tongi, Gazipur in Bangladesh. Environ Sci \& Natural Resources. 7: 27 - 33.

18. Razzak NRB, Muntasir SY and Chowdhury S. 2012. Pollution scenario of Dhaka city lakes: A case study of Dhanmondi and Ramna lakes. Global Engineers \& Technologists Review. Vol 2, No 7. 